\section{Leafminer-resistant Spinach Germplasm 03-04-9}

\author{
Beiquan Mou' \\ U.S. Dept. of Agriculture (USDA), Agricultural Research Service, \\ 1636 East Alisal Street, Salinas, CA 93905
}

Additional index words. Liriomyza langei, insect resistance, Spinacia oleracea

Leafminers are serious insect pests of many agricultural crops throughout the world (Parrella, 1987). The predominant leafminer species in spinach (Spinacia oleracea L.) production areas in central California was identified to be Liriomyza langei Frick (Scheffer et al., 2001). Leafminer adults are small, shiny, black flies with a bright yellow triangular spot on the upper thorax between the wings. Damage occurs when adult flies puncture leaves to feed on plant sap and females lay white, oval eggs within the leaf tissue, leaving "stings" that appear as holes or bumps on the leaves. Larvae hatch from eggs and feed between upper and lower leaf surfaces. The winding, whitish tunnels or mines they create are initially narrow but increase in width as the larvae grow. Larvae emerge from the mines after completing three instars and pupate in cracks in the soil or on the leaf surface. Adult flies come out of pupae in $\approx 8-11 \mathrm{~d}$. The entire life cycle can be completed in less than 3 weeks in warm weather, and many generations are produced each year in California. Damage incited by adult stings and larval mining of leaves reduces photosynthetic capacity, renders spinach leaves unmarketable, and provides an entrance for disease organisms (LeStrange et al., 1999).

Chemical control of leafminers usually lasts only a short time. Adult control with contact insecticides is especially unsatisfactory because flies can easily move, and the treated field is subject to re-infestation from adjacent untreated crops and weeds (LeStrange et al., 1999). Many studies have shown that leafminers can develop a high degree of resistance to a broad range of

Received for publication 16 Nov. 2006. Accepted for publication 9 Dec. 2006.

Mention of a trade name, proprietary product, or vendor does not constitute an endorsement, guarantee, or warranty by the USDA and does not imply its approval to the exclusion of other products or vendors that may be suitable.

We thank JoAnn Tanaka and Sharon Benzen for technical assistance and Jan Dijkstra and Margaret Savage for critical review and discussion of the $m$ anuscript. We also thank the USDA North Central Regional Plant Introduction Station, Ames, Iowa, for providing seeds of the spinach collection for this research.

${ }^{1}$ Research Geneticist; to whom correspondence should be addressed;

e-mailbmou@pw.ars.usda.gov. insecticides (Keil and Parrella, 1990; Mason et al., 1987; Parrella and Trumble, 1989). In California, chemical control is often not an option for spinach. Fresh market "baby leaves" are harvested in about $24 \mathrm{~d}$ from planting (at the four- to five-leaf stage). Many systemic insecticides for larval control have a requirement of a 14-d preharvest interval (the period with no chemical sprays before harvest). The result is that "baby leaf" fields have to be sprayed about $10 \mathrm{~d}$ after planting or earlier, when plants are still small and most of the spray hits the ground and is wasted. Consequently, growers try to avoid leafminers by planting spinach in fields where the insect pressure is low, but growers may not have that option and leafminer infestation is unpredictable. As a result, spinach is often tainted with the stipples of adult feeding or tunnels (mines) from larva feeding, reducing quality, appearance, and value. Therefore, it is essential to develop alternative management strategies for leafminers.

Resistant cultivars remain the most economical means of insect control. Their use will reduce the costs of chemicals, energy, and labor associated with pesticide spraying. In addition, resistant cultivars will reduce worker exposure and pesticide residues on food and in the environment. However, spinach cultivars with high levels of resistance to leafminers are not currently available. With the rising demand and increasing production for spinach products, there is an urgent need of leafminer resistance in spinach. In this report, a leafminer-resistant spinach germplasm is described.

\section{Origin}

Research was conducted at the Agricultural Research Station of the USDA, Salinas, Calif. The 332 spinach accessions from the National Plant Germplasm System, USDA (North Central Regional Plant Introduction Station, Ames, Iowa), were screened for leafminer resistance in a preliminary field study in 2002 (B. Mou, unpublished results). No accession was immune to leafminers, but partial resistance was found in some individual plants within some accessions. A recurrent selection breeding method was used to increase the level of resistance to leafminers. Thirteen plants with fewer leafminer mines were selected from several accessions (five plants from PI 174385, four plants from PI 169673, three plants from PI 175312, and one plant from PI 604787) and were moved to pollinate each other in isolation in 2002. About 400 seeds were harvested from these plants and planted in the field in 2003 for another round of selection. Twenty-seven plants with fewer leafminer mines were selected and allowed to pollinate each other in isolation. Seeds were harvested from these plants to produce the breeding line 03-04-9.

\section{Description}

Insect resistance. The breeding line 03-04-9 was planted in fields at the Hartnell College in July 2004 (Trial 1) and at the USDA Agricultural Research Station in Aug. 2004 (Trial 2) and Aug. 2005 (Trial 3) in Salinas, Calif., to evaluate its resistance to leafminers. Commercial spinach cultivars 'Alrite' (American Takii, Salinas, Calif.), 'Hellcat' (Seminis Vegetable Seeds, Woodland, Calif.), 'Lion' (Rijk Zwaan, De Lier, Holland), and 'Nordic IV' and 'Springfield' (Gowan Seed Co., Salinas, Calif.) were included in the trials. Experimental design was a randomized complete block with 8 replications. Each plot consisted of 10 plants of a genotype, with $30 \mathrm{~cm}$ between plants and $35 \mathrm{~cm}$ between rows on 1-m wide doublerow beds. Numbers of leafminer mines on each plant were counted 6 weeks after planting. Plant weight excluding roots was also recorded for each plant. Per-plant values were averaged, and analysis was conducted on the basis of plot means. Data were analyzed by analysis of variance (ANOVA) using the general linear model procedure of JMP, v. 5 (SAS Institute, Cary, N.C.). Genotypes were considered fixed effects, and replications were considered random effects. For comparisons between genotypes, least significant differences (LSD) were calculated with an error rate of $P=0.05$.

Breeding line 03-04-9 had significantly fewer leafminer mines per plant than the commercial cultivars tested (Table 1). 0304-9 had 14.4, 6.6, and 5.2 mines per plant in Trials 1,2, and 3 , while commercial cultivars averaged 129.3, 69.4, and 54.6 mines per plant in the three trials, respectively. Because 03-04-9 had lower plant weight than the cultivars, mines per plant were divided by plant weight to derive mines per $100 \mathrm{~g}$ plant weight. Breeding line 03-04-9 exhibited significantly fewer mines per unit plant weight than the cultivars. 03-04-9 had 17.9, 8.3, and 11.0 mines per $100 \mathrm{~g}$ plant weight in Trials 1,2 , and 3 , compared with the averages of $58.9,28.5$, and 49.9 mines per $100 \mathrm{~g}$ for commercial cultivars in the three trials, respectively. Although this breeding line is resistant to mines, it was not resistant to damage from leafminer stings.

Morphological character. 03-04-9 is an "oriental" type (leaves have deep indents as compared with spinach commonly found in the West with round leaves) of spinach with dark green, semi-erect leaves (Fig. 1). It has an oak-leaf like leaf shape with two deep indents on both sides of the leaf blade. Leaf 
Table 1. Means and least significant differences (LSD) at $P=0.05$ for leafminer mines of spinach cultivars and breeding line 03-04-9 evaluated in field trials in Salinas, Calif., in 2004 (Trials 1 and 2) and 2005 (Trial 3).

\begin{tabular}{|c|c|c|c|c|c|c|c|c|c|}
\hline \multirow[b]{2}{*}{ Genotype } & \multicolumn{3}{|c|}{ Plant $w^{z}(g)$} & \multicolumn{3}{|c|}{ Mine/plant } & \multicolumn{3}{|c|}{ Mine/100 $\mathrm{g} \mathrm{wt}^{\mathrm{y}}$} \\
\hline & Trial 1 & Trial 2 & Trial 3 & Trial 1 & Trial 2 & Trial 3 & Trial 1 & Trial 2 & Trial 3 \\
\hline Lion & $201.2 \mathrm{~b}$ & $212.4 \mathrm{~b}$ & $96.3 \mathrm{~b}$ & $156.5 \mathrm{a}$ & $71.2 \mathrm{ab}$ & $60.6 \mathrm{a}$ & $78.3 \mathrm{a}$ & $35.7 \mathrm{a}$ & $66.5 \mathrm{a}$ \\
\hline Hellcat & $198.4 \mathrm{~b}$ & $197.4 \mathrm{~b}$ & $97.9 \mathrm{~b}$ & $123.1 \mathrm{bc}$ & $57.8 \mathrm{~b}$ & $56.6 \mathrm{ab}$ & $64.8 \mathrm{~b}$ & $31.4 \mathrm{ab}$ & $58.2 \mathrm{ab}$ \\
\hline Nordic IV & $234.6 \mathrm{~b}$ & $280.2 \mathrm{~b}$ & $110.1 \mathrm{~b}$ & $118.9 \mathrm{bc}$ & $75.9 \mathrm{ab}$ & $44.2 \mathrm{~b}$ & $52.7 \mathrm{c}$ & $28.8 \mathrm{ab}$ & $43.2 \mathrm{c}$ \\
\hline Springfield & $237.3 \mathrm{~b}$ & $255.3 \mathrm{~b}$ & $115.7 \mathrm{~b}$ & $110.4 \mathrm{c}$ & $63.7 \mathrm{ab}$ & $57.3 \mathrm{a}$ & $48.9 \mathrm{c}$ & $26.2 \mathrm{bc}$ & $51.7 \mathrm{bc}$ \\
\hline Alrite & $308.7 \mathrm{a}$ & $458.9 \mathrm{a}$ & $184.2 \mathrm{a}$ & $137.4 \mathrm{ab}$ & $78.5 \mathrm{a}$ & $54.1 \mathrm{ab}$ & $50.0 \mathrm{c}$ & $20.5 \mathrm{c}$ & $29.8 \mathrm{~d}$ \\
\hline 03-04-9 & $86.3 \mathrm{c}$ & $91.7 \mathrm{c}$ & $47.0 \mathrm{c}$ & $14.4 \mathrm{~d}$ & $6.6 \mathrm{c}$ & $5.2 \mathrm{c}$ & $17.9 \mathrm{~d}$ & $8.3 \mathrm{~d}$ & $11.0 \mathrm{e}$ \\
\hline $\operatorname{LSD}_{0.05}$ & 53.0 & 84.1 & 29.2 & 21.4 & 19.6 & 12.4 & 10.9 & 7.3 & 9.6 \\
\hline
\end{tabular}

${ }^{\mathrm{z}}$ Means within a column followed by the same letter are not significantly different at $P=0.05$.

${ }^{y}$ Number of mines per $100 \mathrm{~g}$ fresh plant weight.

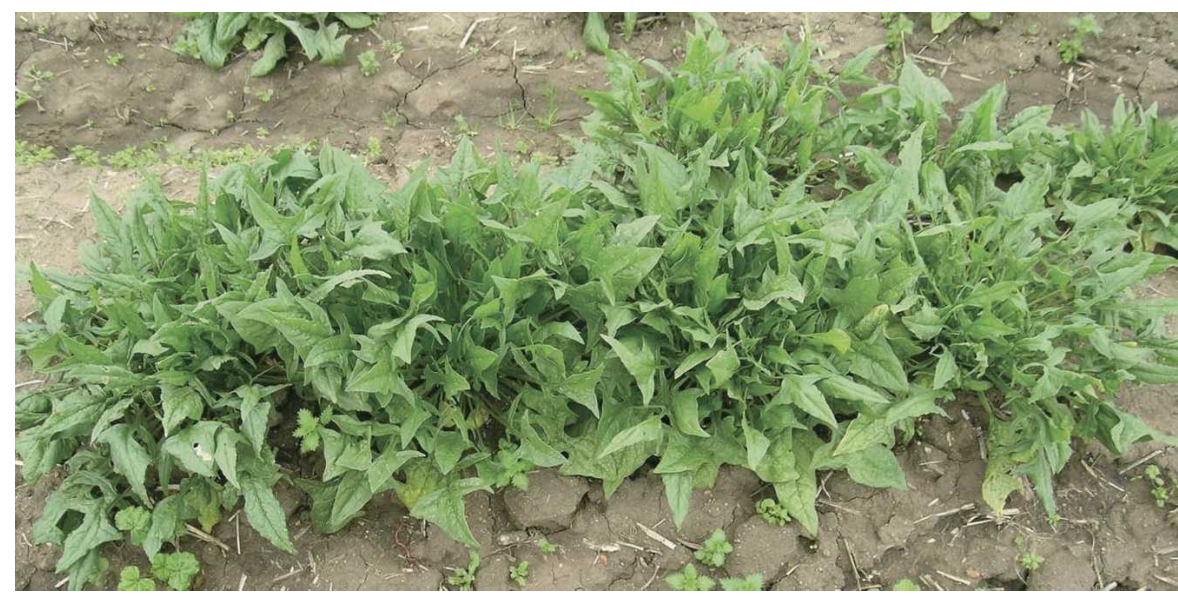

Fig. 1. Spinach germplasm 03-04-9 in the field.

surface is semi-flat. Red color appears on stems, petioles, and anthers. It has a dioecious flowering habit and produces prickly seeds. It has moderate resistance to bolting as compared with other germplasm accessions. Breeding line 03-04-9 was susceptible to a field infection of downy mildew (Peronospora farinose f. sp. spinaciae Byford), although the race of the pathogen was not determined.

\section{Seed Availability}

Limited samples of seed are available from the author for distribution to all interested parties for research purposes, including the development and commercialization of new cultivars. Samples will also be deposited in the National Plant Germplasm System. It is requested that appropriate recognition be made if the 03-04-9 germplasm contributes to research or the development of new germplasm, breeding lines, inbreds, or cultivars.

\section{Literature Cited}

Keil, C.B. and M.P. Parrella. 1990. Characterization of insecticide resistance in two colonies of Liriomyza trifolii (Diptera: Agromyzidae). J. Econ. Entomol. 83:18-26.

LeStrange, M., S. Koike, J. Valencia, and W. Chaney. 1999. Spinach production in California, p. 3-4. Univ. of Calif., Div. of Agr. and Nat. Resources, Publication 7212.

Mason, G.A., M.W. Johnson, and B.E. Tabashnik. 1987. Susceptibility of Liriomyza sativae and Liriomyza trifolii (Diptera: Agromyzidae) to permethrin and fenvalerate. J. Econ. Entomol. 80:1262-1266.

Parrella, M.P. 1987. Biology of Liriomyza. Annu. Rev. Entomol. 32:201-224.

Parrella, M.P. and J.T. Trumble. 1989. Decline of resistance in Liriomyza trifolii (Diptera: Agromyzidae) in the absence of insecticide selection pressure. J. Econ. Entomol. 82:365368.

Scheffer, S.J., A. Wijesekara, D. Visser, and R.H. Hallett. 2001. Polymerase chain reactionrestriction fragment-length polymorphism method to distinguish Liriomyza huidobrensis from L. langei (Diptera: Agromyzidae) applied to three recent leafminer invasions. J. Econ. Entomol. 94:1177-1182. 